\title{
Germination Stimulation of Striga gesnerioides Seeds by Hosts and Nonhosts
}

\author{
D. K. Berner and O. A. Williams, International Institute of Tropical Agriculture, Ibadan, Nigeria, c/o L. W. Lam- \\ bourn \& Co., Carolyn House, 26 Dingwall Road, Croydon, CR9 3EE, England
}

\begin{abstract}
Berner, D. K., and Williams, O. A. 1998. Germination stimulation of Striga gesnerioides seeds by hosts and nonhosts. Plant Dis. 82:1242-1247.

Cowpea (Vigna unguiculata) is an important source of protein in Africa, but production is hindered by the parasitic plant Striga gesnerioides. Crop rotation with nonhost cultivars, selected to stimulate parasite seed germination, is being used successfully to control other Striga spp. and may have potential to control $S$. gesnerioides. Little information has been available on nonhosts of $S$. gesnerioides that are capable of stimulating germination of parasite seeds. A laboratory procedure was used to evaluate species and cultivars for their ability to stimulate $S$. gesnerioides seed germination. Genotypes of all Vigna spp. tested stimulated parasite seed germination. Some genotypes of the nonhost species Cajanus cajan, Lablab purpureus, Sphenostylis stenocarpa, and Sorghum bicolor also stimulated parasite seed germination. One cultivar of Sorghum bicolor stimulated significantly more germination than any other cultivar or species. Control of S. gesnerioides through rotation with selected nonhost cultivars has potential if selection is done with the parasite isolate(s) from the locality of intended use. When seeds of single-plant isolates of $S$. gesnerioides were tested against roots of seedlings from Sorghum bicolor landraces and from a susceptible cowpea cultivar, only specific isolate and plant combinations resulted in parasite seed germination. These specific interactions have broader implications for parasite survival.
\end{abstract}

Additional keywords: germination stimulants, sorghum, Striga control

The relatively high protein content of cowpea (Vigna unguiculata (L.) Walp.) makes it an important supplement to the diet of many African people (7) who consume cereals, roots, and tubers high in carbohydrate and low in protein. Cowpea is used for both food and forage $(1,7,23)$ and is frequently intercropped with cereals where crop mixes with cowpea are beneficial in maintaining soil fertility $(8,9)$. In Africa, cowpea generally produces low yields, which are further depressed by pests and diseases $(1,3,9)$. Parasitism by Striga gesnerioides (Willd.) Vatke, an obligate root-parasitic flowering plant of the Scrophulariaceae family (15), can cause yield reductions as high as 83 to $100 \%$ on susceptible cowpea cultivars in sub-Saharan Africa $(2,9)$.

$S$. gesnerioides is an autogamous parasite, the seeds of which are the sole inoculum. The life cycle is typical of other agriculturally important Striga spp. Seed germination requires both inbibition of water at a suitable temperature and an exogenous germination stimulant, which is usually a host-root exudate (26). In the absence of a specific germination stimu-

Corresponding author: D. K. Berner

E-mail: d.berner@cgnet.com

Accepted for publication 30 July 1998.

Publication no. D-1998-0826-01R

(C) 1998 The American Phytopathological Society lant, germination does not occur, even under favorable environmental conditions $(15,26)$. If the germinated seedling does not attach to a host and successfully establish a parasitic link within 3 to 7 days, the seedling dies. If a host root is in close proximity ( 2 to $3 \mathrm{~mm}$ ) to the germinated seedling, the parasite radicle forms a haustorium (12), attaches to the host root, and establishes a xylem-to-xylem connection $(15,20)$. Numerous seedlings can often be found attached to the same plant, often the same root. Several attachments to the host root system can be made from each attached parasite (10). After successful attachment, S. gesnerioides plants develop for 4 to 5 weeks prior to emergence (10). After emergence, the plants form chlorophyll and begin to flower 4 to 7 days later (10). Each parasitic plant is capable of producing 50,000 to 500,000 seeds (1), which are extremely small, each weighing about $6 \mu \mathrm{g}$ (20).

Morphotypes of S. gesnerioides occur and are distinguishable by stem succulence, internode length, flower color, and size $(15,17,20)$. Hosts include cowpea, species of Alysicarpus, Euphorbia, Indigofera, Ipomea, Jacquemontia, Merremia, and Tephrosia, and Nicotiana tabacum (20). There is considerable variation in host specificity between isolates of $S$. gesnerioides, and different host species vary in their susceptibility to different isolates of $S$. gesnerioides $(15,17,24)$.

Several identified mechanisms of cowpea resistance to $S$. gesnerioides are ex- pressed as different types of postattachment hypersensitive responses $(6,9,14,22)$. Several races of $S$. gesnerioides have been identified based on differential resistance reactions of cowpea cultivars $(13,14,18,22)$. Because of the autogamous nature of $S$. gesnerioides, variations among isolates become genetically fixed, and geographic distributions of morphotypes, strains, and races frequently overlap $(16,17,20)$.

A successful means of control for other Striga spp. has been stimulation of parasite seed germination in the absence of a host. In the United States, ethylene gas has been used to stimulate Striga asiatica (L.) Kuntze seed germination in the absence of hosts and to eradicate the parasite from farmers' fields (21). In Africa, nonhost (particularly legume) cultivars selected for their efficiency in inducing Striga hermonthica (Del.) Benth. seed germination are being used in rotation with cereals to control $S$. hermonthica $(5,6)$. The use of nonhost legumes for $S$. gesnerioides control also has been suggested $(11,25)$, but virtually no attention has been placed on cereal species, which are commonly grown in rotation (or as crop mixtures) with cowpea. Root exudates of the species Abrus pricatorius, Cajanus cajan, Calapogonium sp., Glycine max, Pueraria sp., and Vigna unguiculata have been identified as effective in stimulating $S$. gesnerioides seed germination (11). When seeds of S. gesnerioides were placed on roots of different plant species, germination was observed on roots of C. cajan, Digitaria sanguinalis, $G$. max, Rottboellia exaltata L.f., Sorghum bicolor, and V. unguiculata (19). Aside from this single reference to an unidentified cultivar of Sorghum bicolor, there appear to be no other reports on $S$. gesnerioides seed germination by cultivated cereal species. No information seems to exist on the variability among cultivars or accessions of cultivated cereals in their ability to stimulate seed germination of different $S$. gesnerioides isolates. The objectives of this study were to: (i) identify species and cultivars of nonhost plants, particularly cereals, that might be capable of stimulating $S$. gesnerioides seed germination and be useable, in rotation with cowpea, to control S. gesnerioides; and (ii) determine whether interactions for stimulation of parasite seed germination occur between cultivars of plants and S. gesnerioides isolates from cowpea and whether these interactions have any bearing on control. 


\section{MATERIALS AND METHODS}

Collection of plant materials. Seeds of $S$. gesnerioides were collected from different parasite plants growing on a local cowpea cultivar in a single field in Bagauda, Nigeria, in 1992. The Bagauda population was used in studies on variation in the ability of plant species and cultivars to stimulate $S$. gesnerioides seed germination. Seeds of host and nonhost cultivars were obtained from collections maintained at the International Institute of Tropical Agriculture (IITA), Ibadan, Nigeria.

Studies on germination of seeds of $S$. gesnerioides isolates by different cultivars of plants (to determine whether interactions occur) were conducted with parasite seeds collected from single parasite plants growing on cowpea. These collections were made in farm fields around 12 towns selected arbitrarily in the northern savanna (120- to 150-day growing season) of Nigeria (Table 1). Isolates were named after the location from which they were collected. The nonhost cultivars used in these studies were landraces of millet (Pennisetum glaucum) and sorghum (Sorghum bicolor). Seeds of millet and sorghum landraces were collected from individual plants growing in farm fields around 45 towns selected arbitrarily in the same area. A landrace was defined as a single sorghum panicle or millet spike collected from an individual location. Landraces were named according to the town near which they were collected. In cases where millet and sorghum seeds were collected from the same towns as the $S$. gesnerioides isolates, the cereal seeds were collected from the same or adjacent fields as the $S$. gesnerioides isolates. The host (cowpea) cultivar used was IT84S-2246-4, which is IITA's generic S. gesnerioides-susceptible check in cowpea breeding trials $(9,22)$.

General preparation and testing procedures. All experiments were conducted

Table 1. Viability of seeds from single plants (isolates) of Striga gesnerioides collected from 12 sites in Nigeria and from a population of $S$. gesnerioides plants from Bagauda, Nigeria

\begin{tabular}{lcc}
\hline $\begin{array}{l}\text { S. gesnerioides } \\
\text { isolate }^{\mathbf{a}}\end{array}$ & $\begin{array}{c}\text { Mean viability } \\
(\boldsymbol{\%})^{\mathbf{b}}\end{array}$ & $\begin{array}{c}\text { Standard } \\
\text { error }\end{array}$ \\
\hline Akayafi & 15.5 & 3.4 \\
Balbadu & 24.6 & 5.8 \\
Bagauda & 38.2 & 7.9 \\
(population) & & \\
Bauchi & 33.3 & 8.7 \\
Bulkachuwa & 23.5 & 4.8 \\
Darazo & 37.4 & 9.0 \\
Dorum & 12.7 & 3.5 \\
Fandi & 17.9 & 4.4 \\
Ningi & 20.8 & 5.5 \\
Sade & 33.9 & 8.7 \\
Yana & 21.3 & 5.1 \\
Zandan & 30.2 & 5.9 \\
Zigau & 29.7 & 6.9 \\
\hline
\end{tabular}

a Isolate name corresponds to site of collection.

${ }^{b}$ Means based on four replications; each conducted on a different day. in the laboratory and screenhouse at IITA, Ibadan, Nigeria, from June 1993 through June 1995. The laboratory procedure used to quantify germination stimulation of $S$. gesnerioides seeds was adapted from a procedure used to select nonhost legumes for germination stimulation of $S$. hermonthica seeds (5). Seeds of S. gesnerioides need to be conditioned to respond to germination stimulants by exposing the seeds to water and incubating them at a favorable temperature for a suitably long period of time. Four-month-old $S$. gesnerioides seeds from the Bagauda population were surfacedisinfested for $5 \mathrm{~min}$ in an aqueous $1 \%$ $\mathrm{NaOCl}$ solution. Floating seeds were discarded. The remaining seeds were air-dried and placed on 5-mm-diameter moist glassfiber filter-paper (Whatman GF/C) disks. Approximately $50 \mathrm{~S}$. gesnerioides seeds were placed on each disk, and the disks were placed on two moistened Whatman no. 1 filter papers in a petri dish. About 60 disks were placed in any one petri dish for a total of about 3,000 seeds. The dishes were then placed in incubators set at $28^{\circ} \mathrm{C}$ and kept in darkness for 14 days. After incubation, the glass-fiber disks with the conditioned $S$. gesnerioides seeds were removed from the petri dishes and placed in a clean 9-cm-diameter petri dish. The disks were placed around a 2-cm-diameter aluminum foil ring, centered in the petri dish, on freshly moistened filter papers (Whatman no. 1). The disks were arranged in four lines forming a cross radiating from the central aluminum foil ring. Each line had five disks, with the first disk in each line touching the central ring and subsequent disks touching. This resulted in the disks occupying spaces 0 to 5,5 to 10,10 to 15,15 to 20 , and 20 to $25 \mathrm{~mm}$ from the central ring (Fig. 1).

Seedlings of the cultivars to be tested were grown in sterilized sand in 250-ml plastic cups (three to five seedlings per cup) in a screenhouse at IITA. Plants were grown for 3 weeks, after which they were gently removed from the cups, and the roots were washed free of sand with deionized water. Roots of the seedlings were cut into $1-\mathrm{cm}$-long pieces, and $1.5 \mathrm{~g}$ of root pieces were weighed and placed into the central aluminum foil ring around which the disks with conditioned S. gesnerioides seeds had been placed. After the root pieces were weighed and placed in the central ring, $300 \mu \mathrm{l}$ of sterile deionized water was pipetted over the root pieces to help diffuse root exudates. In the negative controls, $300 \mu \mathrm{l}$ of sterile deionized water was substituted for the root pieces. The root pieces, controls, and parasite seeds were then incubated together at $28^{\circ} \mathrm{C}$ for 5 days. Percent germination on each disk was checked daily. After 5 days, the final percent germination on each disk was calculated and then average percent germination for each line of disks, i.e., from 0 to 25 $\mathrm{cm}$ from the stimulant source, in each petri dish was calculated. The mean germination from each line of disks in each petri dish was transformed by arcsine [square root (mean proportion germination)]. The transformed values were used in statistical analyses to determine levels of significance associated with means and differences in means. For ease of interpretation, the means and standard deviations of percent germination data were determined with raw means, and adjusted germination was determined by dividing mean percent ger-

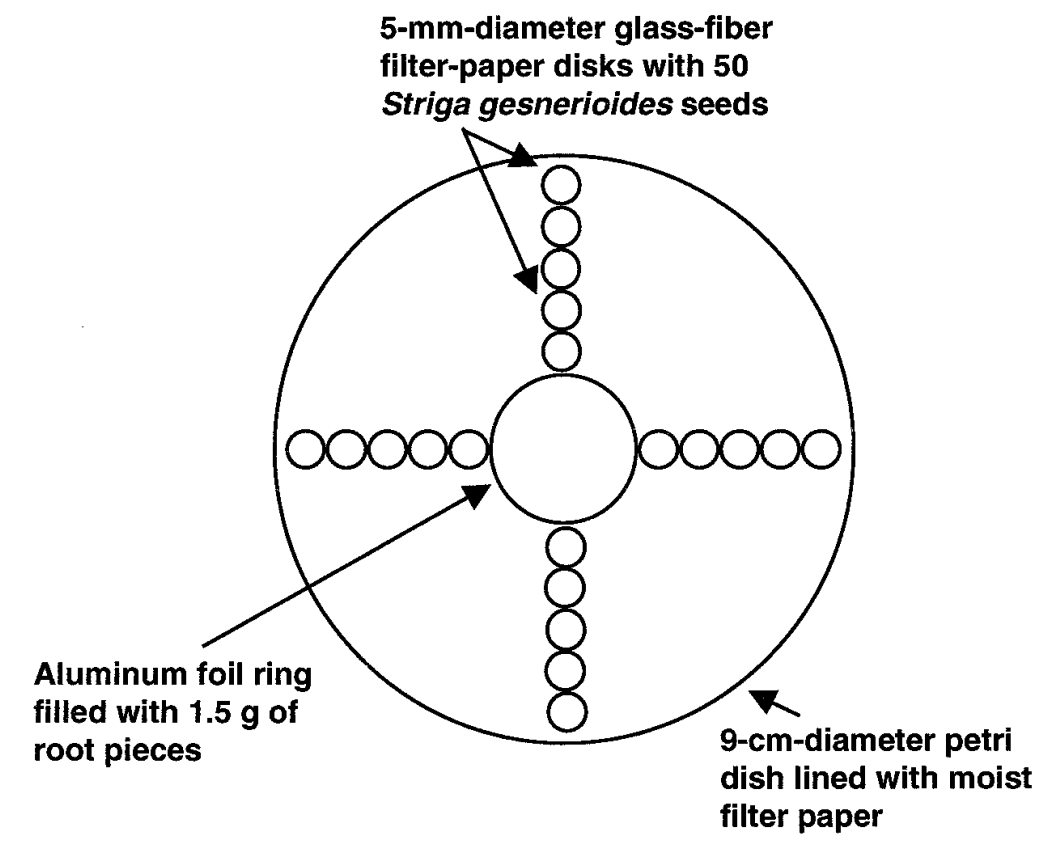

Fig. 1. Petri dish setup for testing hosts and nonhosts for germination stimulation of Striga gesnerioides seeds. 
mination by the proportion of viable $S$. gesnerioides seeds.

Viability of the seeds of each parasite isolate was determined immediately after completion of each test. About 100 seeds of each parasite isolate were placed in separate petri dishes, and $5 \mathrm{ml}$ of $9 \times 10^{-2}$ M triphenyl tetrazolium chloride was added to cover the seeds (4). The petri dishes were then incubated in darkness for 8 days at $31^{\circ} \mathrm{C}$. The tetrazolium chloride solution was then poured off, and $5 \mathrm{ml}$ of commercial bleach was added for about 5 min until the seed coats were clear. After clearing the seed coats, viable seeds, evidenced by red-stained embryos, were counted and percent viability determined. Viability tests were repeated on 4 separate days for each parasite isolate.

Germination stimulated by different plant species and cultivars. Cultivars of 24 plant species (Table 2) were tested for their ability to stimulate seed germination of the Bagauda population of $S$. gesnerioides. Testing was done as described in the previous section using $300 \mu \mathrm{l}$ of sterile distilled water as a control. Root pieces were cut from one to five seedlings per cultivar to obtain $1.5 \mathrm{~g}$ of roots, which was used as the germination stimulant source. If an adequate amount of roots were available, tests were repeated on 6 different days, with each cultivar being tested on each day. Otherwise, each cultivar was tested, along with the other cultivars, until there was no longer an adequate amount of roots for further testing. For this reason, some cultivars could only be tested twice. Percent germination on each disk in each petri dish was checked daily. The average percent germination per line of disks was calculated, and the averages were transformed as previously described. Means of percent germination and the transformed values were calculated for each petri dish (average of four lines) of each cultivar in each test. Means of percent germination data were analyzed by the UNIVARIATE procedure of SAS (Statistical Analysis System, Rel. 6.12, SAS Institute, Cary, NC) to generate raw means and standard deviations. Tests of the null hypothesis that the germination stimulated by each species or cultivar equaled zero were done with transformed values and the UNIVARIATE procedure. Analyses of variance of the transformed values for each species and cultivar were done by the GLM procedure

Table 2. Seed germination of Striga gesnerioides, Bagauda population, stimulated by root pieces of different plant species

\begin{tabular}{|c|c|c|c|c|c|}
\hline Species/common name & $\begin{array}{c}\text { Actual } \\
\text { germination }^{\mathrm{a}}\end{array}$ & $\mathbf{N}^{\mathbf{b}}$ & Std $^{\mathrm{c}}$ & $P^{d}$ & $\begin{array}{c}\text { Adjusted } \\
\text { germination }^{\mathrm{e}}\end{array}$ \\
\hline Arachis hypogea/peanut & 0.0 & 4 & 0.0 & 1.00 & 0.0 \\
\hline $\begin{array}{l}\text { Brassica oleracea var. capitatal } \\
\text { cauliflower }\end{array}$ & 0.0 & 3 & 0.0 & 1.00 & 0.0 \\
\hline $\begin{array}{l}\text { B. oleracea } \text { var. botrytis/ } \\
\text { cabbage }\end{array}$ & 0.3 & 2 & 0.4 & 0.50 & 0.8 \\
\hline Cajanus cajan/pigeon pea & 3.6 & 19 & 4.3 & $<0.01$ & 9.5 \\
\hline Celosia argentea/celosia & 0.0 & 2 & 0.0 & 1.00 & 0.0 \\
\hline Сиситis melo/melon & 0.1 & 4 & 0.1 & 0.06 & 0.3 \\
\hline C. sativus/cucumber & 0.0 & 4 & 0.0 & 1.00 & 0.0 \\
\hline Glycine max/soybean & $<0.1$ & 35 & 0.2 & 0.12 & $<0.3$ \\
\hline Hibiscus esculentus/okra & 0.1 & 4 & 0.1 & 0.18 & 0.3 \\
\hline Lablab purpureus/bonavist bean & 2.7 & 19 & 3.1 & $<0.01$ & 7.1 \\
\hline $\begin{array}{l}\text { Mucuna pruriens var. utilis/ } \\
\text { Florida velvet bean }\end{array}$ & 0.0 & 5 & 0.0 & 1.00 & 0.0 \\
\hline Oryza sativa/rice & 0.0 & 9 & 0.0 & 1.00 & 0.0 \\
\hline Pennisetum glaucum/pearl millet & 0.1 & 4 & 0.1 & 0.18 & 0.3 \\
\hline $\begin{array}{l}\text { Psophocarpus tetragonolobus / } \\
\text { winged bean }\end{array}$ & 1.4 & 11 & 2.1 & 0.04 & 3.7 \\
\hline $\begin{array}{l}\text { Pueraria phaseoloides / } \\
\text { tropical kudzu }\end{array}$ & 0.0 & 2 & 0.0 & 1.00 & 0.0 \\
\hline Sesamum indicum/sesame & 0.4 & 4 & 0.1 & 0.02 & 1.1 \\
\hline Sorghum bicolor/sorghum & 4.4 & 51 & 10.8 & $<0.01$ & 11.6 \\
\hline $\begin{array}{l}\text { Sphenostylis stenocarpal } \\
\text { African yam bean }\end{array}$ & 2.6 & 16 & 2.0 & $<0.01$ & 6.8 \\
\hline Vigna radiata/mung bean & 13.8 & 17 & 6.2 & $<0.01$ & 36.3 \\
\hline V. subterranea/bambara nut & 4.9 & 33 & 8.4 & $<0.01$ & 12.9 \\
\hline V. umbellata/rice bean & 9.6 & 8 & 6.0 & $<0.01$ & 25.3 \\
\hline V. unguiculata/cowpea & 13.4 & 18 & 3.5 & $<0.01$ & 35.3 \\
\hline$V$. vexillata/wild vigna & 3.9 & 4 & 2.0 & $<0.01$ & 10.3 \\
\hline Zea mays/maize & 0.0 & 12 & 0.0 & 1.00 & 0.0 \\
\hline
\end{tabular}

${ }^{a}$ Mean percent germination (mean of five disks) was calculated for each of four lines of filter paper disks in a petri dish. Mean germination per petri dish (mean of four lines) for each plant species was analyzed to generate overall means and standard deviations for each species.

${ }^{\mathrm{b}}$ Number of petri dishes analyzed.

${ }^{\mathrm{c}}$ Standard deviation for mean percent germination.

${ }^{\mathrm{d}}$ Probability of a greater $\mathrm{T}$ value, under the null hypothesis that the mean equaled zero, based on arcsine (square root) transformation of percent germination data.

e Actual germination adjusted for percent viability of the $S$. gesnerioides seeds. of SAS. Single degree-of-freedom contrasts were conducted to test specific comparisons of interest.

Germination of seeds of $S$. gesnerioides isolates by cowpea and cereal landraces. The ability of different landraces of sorghum and millet and a cowpea cultivar to stimulate germination of seeds of different $S$. gesnerioides isolates was investigated to determine whether interactions for parasite seed germination occur between cereals and $S$. gesnerioides isolates. An initial test was made on cowpea, IT84S2246-4, with $12 \mathrm{~S}$. gesnerioides isolates. The test was conducted as previously described.

Subsequent tests were made on 45 sorghum and 45 millet landraces with the same $12 \mathrm{~S}$. gesnerioides isolates. Because of the limited amount of seeds from individual cereal plants and $S$. gesnerioides isolates, it was not possible to conduct multiple tests with every parasite isolate and plant combination. An initial test was conducted with each parasite isolate and cereal landrace. This test was conducted as described, but transformed percent germination of each line of disks in a petri dish was used as a sample of the particular isolate-landrace combination. The null hypotheses that the germination stimulated by each parasite isolate and landrace combination equaled zero were tested as previously described. To conserve seeds of parasite isolates and landraces, only those isolate-landrace combinations that produced significant $(P \leq 0.01)$ germination were tested twice again, if adequate parasite and plant seeds were available. After testing these combinations again, any remaining parasite and plant seeds were used to test several randomly selected combinations that had produced no germination in the initial test. Analyses of variance of the means of the transformed values of each isolate-landrace combination from the separate tests were done by the GLM procedure of SAS. Tests of the null hypotheses, that the population marginal means generated from the different tests equaled zero, were done using the LSMEANS statement with GLM.

\section{RESULTS}

Germination stimulated by different plant species and cultivars. Viability of seeds of the Bagauda population of $S$. gesnerioides was $38.2 \%$ (Table 1). Stimulation of germination of these seeds by 24 plant species showed that nine of the species were stimulant producers (Table 2). Mean germination of $S$. gesnerioides seeds, adjusted for seed viability, ranged from 6.8 to $36.3 \%$ for the nine stimulant-producing species. Members of the genus Vigna stimulated significantly more seed germination in the Bagauda population of $S$. gesnerioides than did all other species (Table 3). The greatest amount of germination was stimulated by the host $V$. un- 
guiculata and by $V$. radiata, which is not a known host. Each of these two species stimulated significantly more germination than all other Vigna spp. combined (Table $3)$. Other than the species of Vigna, only C. cajan and Sphenostylis stenocarpa stimulated significantly more parasite seed germination than other species (Table 3). However, they stimulated significantly less germination than Vigna spp. Although $L$. purpureus and Sorghum bicolor stimulated germination of parasite seeds, they did not stimulate significantly more germination than other species. The lack of significance was probably due to relatively large standard deviations, in comparison to the means, for these two species.

Stimulation of seed germination in the Bagauda population of $S$. gesnerioides by different cultivars or accessions of the different species was highly variable, ranging from 0 to $93.4 \%$ adjusted germination (Table 4). Most accessions of Vigna spp. stimulated germination of $S$. gesnerioides seeds, with a range in adjusted germination from 10.3 to $61.8 \%$. Cultivars of $V$. unguiculata stimulated germination that ranged from 15.8 to $44.2 \%$. The ranges in germination of $S$. gesnerioides seeds stimulated by $V$. radiata and $V$. subterranea (not known hosts) were similar to V. unguiculata. However, cultivars Tvr34 of $V$. radiata and Tvsu 745 of $V$. subterranea stimulated significantly more germination than all other Vigna and V. unguiculata cultivars combined (Table 5). Cultivar Tvsu 745 also stimulated significantly more germination than the $V$. unguiculata cultivar 86711-the cultivar that stimulated more germination than any other cultivar of $V$. unguiculata. There were no significant differences in amounts of germination stimulated be-

Table 3. Estimates of differences in mean seed germination of Striga gesnerioides, Bagauda population, stimulated by root pieces of different plant species

\begin{tabular}{|c|c|c|}
\hline \multirow[b]{2}{*}{ Species } & \multicolumn{2}{|c|}{$\begin{array}{c}\text { Est. differences in } \\
\text { means }^{\text {a }}(\text { row - column })\end{array}$} \\
\hline & All other sp. & Vigna spp. \\
\hline Cajanus cajan & $2.9 * \mathrm{~b}$ & $-14.4 * *$ \\
\hline Lablab purpureus & $0.5 \mathrm{NS}$ & \\
\hline Sorghum bicolor & $5.0 \mathrm{NS}$ & $-12.3 * *$ \\
\hline $\begin{array}{l}\text { Sphenostylis } \\
\text { stenocarpa }\end{array}$ & $0.3 *$ & $-17.3 * *$ \\
\hline Vigna spp. & $21.7 * *$ & \\
\hline V. radiata & $31.1 * *$ & $15.3 * * \mathrm{c}$ \\
\hline V. unguiculata & $30.0 * *$ & $14.1 * * \mathrm{~d}$ \\
\hline \multicolumn{3}{|c|}{$\begin{array}{l}\text { a Estimates and significance based on contrasts } \\
\text { from ANOVA of arcsine (square root) trans- } \\
\text { formation of unadjusted percent germination. } \\
\text { Differences in percent germination adjusted } \\
\text { for viability of } S \text {. gesnerioides seeds are pre- } \\
\text { sented. } \\
\text { b NS, not significant; } *, P \leq 0.05 ; * *, P \leq 0.01 \text {. } \\
\text { c Vigna spp. do not include } V \text {. radiata for this } \\
\text { estimate. } \\
\text { d Vigna spp. do not include } V \text {. unguiculata for } \\
\text { this estimate. }\end{array}$} \\
\hline
\end{tabular}

Table 4. Seed germination of Striga gesnerioides, Bagauda population, stimulated by root pieces of cultivars of plant species

\begin{tabular}{|c|c|c|c|c|c|}
\hline $\begin{array}{l}\text { Species } \\
\text { Cultivar }\end{array}$ & $\begin{array}{c}\text { Actual } \\
\text { germination }^{\mathrm{a}}\end{array}$ & $\mathbf{N}^{\mathbf{b}}$ & $\operatorname{Std}^{\mathrm{c}}$ & $P^{d}$ & $\begin{array}{c}\text { Adjusted } \\
\text { germination }\end{array}$ \\
\hline \multicolumn{6}{|l|}{ Cajanus cajan } \\
\hline Cits 1 & 0.0 & 3 & 0.0 & 1.00 & 0.0 \\
\hline Cits 2 & 8.3 & 4 & 3.7 & 0.02 & 21.8 \\
\hline Cits 4 & 5.2 & 4 & 4.5 & 0.11 & 13.6 \\
\hline Tcc 8126 & 0.4 & 4 & 0.4 & 0.10 & 1.1 \\
\hline Tcc 8127 & 3.2 & 4 & 4.1 & 0.22 & 8.4 \\
\hline \multicolumn{6}{|l|}{ Lablab purpureus } \\
\hline $\mathrm{T} \ln 1$ & 0.0 & 4 & 0.0 & 1.00 & 0.0 \\
\hline $\mathrm{T} \ln 7$ & 4.3 & 4 & 0.7 & $<0.01$ & 11.3 \\
\hline $\mathrm{T} \ln 28$ & 7.3 & 4 & 2.0 & $<0.01$ & 19.2 \\
\hline$T \ln 31$ & 1.5 & 4 & 1.4 & 0.13 & 3.9 \\
\hline \multicolumn{6}{|l|}{ Sorghum bicolor } \\
\hline Bagauda farafara & 35.5 & 5 & 7.3 & $<0.01$ & 93.4 \\
\hline Kano farafara & 7.5 & 6 & 1.3 & $<0.01$ & 19.7 \\
\hline 10 cultivars or accessions $f$ & \multicolumn{5}{|c|}{ No significant germination stimulation } \\
\hline \multicolumn{6}{|l|}{ Sphenostylis stenocarpa } \\
\hline Tss1 & 1.4 & 4 & 1.0 & 0.08 & 3.7 \\
\hline Tss3 & 4.4 & 2 & 3.3 & 0.31 & 11.6 \\
\hline Tss10 & 1.5 & 3 & 1.1 & 0.14 & 3.9 \\
\hline Tss 15 & 2.6 & 4 & 2.1 & 0.09 & 6.8 \\
\hline Tss60 & 3.9 & 3 & 1.8 & 0.06 & 10.2 \\
\hline \multicolumn{6}{|l|}{ Vigna radiata } \\
\hline Tvr19 & 10.3 & 4 & 4.8 & 0.02 & 27.1 \\
\hline Tvr27 & 12.3 & 4 & 2.4 & $<0.01$ & 32.4 \\
\hline Tvr30 & 14.6 & 4 & 9.1 & 0.05 & 38.4 \\
\hline Tvr34 & 19.5 & 4 & 4.4 & $<0.01$ & 51.3 \\
\hline \multicolumn{6}{|l|}{ V. subterranea } \\
\hline Tvsu323 & 6.3 & 2 & 0.5 & 0.04 & 16.6 \\
\hline Tvsu702 & 10.3 & 4 & 6.5 & 0.05 & 27.1 \\
\hline Tvsu745 & 23.5 & 4 & 8.0 & $<0.01$ & 61.8 \\
\hline 7 cultivars or accessions $\mathrm{g}$ & \multicolumn{5}{|c|}{ No significant germination stimulation } \\
\hline \multicolumn{6}{|l|}{ V. umbellata } \\
\hline Tva1 & 7.0 & 4 & 3.4 & 0.03 & 18.4 \\
\hline Wi140 & 12.2 & 4 & 7.3 & 0.04 & 32.1 \\
\hline \multicolumn{6}{|l|}{ V. unguiculata } \\
\hline 86711 & 16.8 & 4 & 2.3 & $<0.01$ & 44.2 \\
\hline $86 \mathrm{~d} 10$ & 6.0 & 2 & 1.3 & 0.09 & 15.8 \\
\hline $86 \mathrm{~d} 719$ & 12.4 & 4 & 0.9 & $<0.01$ & 32.6 \\
\hline Benin local & 14.4 & 4 & 2.1 & $<0.01$ & 37.9 \\
\hline IT84S-2246-4 & 13.6 & 4 & 1.7 & $<0.01$ & 35.8 \\
\hline \multicolumn{6}{|l|}{ V. vexillata } \\
\hline Tvnu72 & 3.9 & 4 & 2.0 & $<0.01$ & 10.3 \\
\hline
\end{tabular}

${ }^{a}$ Mean percent germination (mean of five disks) was calculated for each of four lines of filter paper disks in a petri dish. Mean germination per petri dish (mean of four lines) for each cultivar was analyzed to generate overall means and standard deviations for each cultivar.

${ }^{\mathrm{b}}$ Number of petri dishes analyzed.

${ }^{c}$ Standard deviation for mean percent germination.

${ }^{\mathrm{d}}$ Probability of a greater $\mathrm{T}$ value, under the null hypothesis that the mean equaled zero, based on arcsine (square root) transformation of percent germination data.

e Actual germination adjusted for percent viability of the Striga gesnerioides seeds.

${ }^{\mathrm{f}}$ CK60B, ICSV247, Kadawa, Kuradd, Lafiya, Mokwalo, Yardu, Yargum, Yarlabe, Yawosan.

g Badeggi, 1034, Tvs1033, Tvsu212, Tvsu870, Tvsu9, Tvsu949.

Table 5. Estimates of differences in mean seed germination of Striga gesnerioides, Bagauda population, stimulated by root pieces of cultivars of plant species

\begin{tabular}{lccccc}
\hline & \multicolumn{5}{c}{ Est. differences in means } \\
\cline { 2 - 5 } $\begin{array}{l}\text { Species } \\
\text { Cultivar }\end{array}$ & $\begin{array}{c}\text { All other } \\
\text { cultivars }\end{array}$ & $\begin{array}{c}\text { All Vigna } \\
\text { cultivars }\end{array}$ & $\begin{array}{c}\text { V. column) } \\
\text { cultivars }\end{array}$ & $\begin{array}{c}\text { V. unguiculata } \\
\text { cv. 86711 }\end{array}$ & $\begin{array}{c}\text { V. subterranea } \\
\text { cv. Tvsu745 }\end{array}$ \\
\hline $\begin{array}{l}\text { Sorghum bicolor } \\
\text { Bagauda farafara }\end{array}$ & $72.5 * * \mathrm{~b}$ & $59.4^{* *}$ & $59.9 * *$ & $49.0 * *$ & $31.4 * *$ \\
$\begin{array}{l}\text { V. subterranea } \\
\text { Tvsu745 }\end{array}$ & & & & & \\
Tvr34 & $40.0 * *$ & $30.1^{\mathrm{c} * *}$ & $28.5 * *$ & $17.5 * *$ & $\ldots$ \\
\hline
\end{tabular}

${ }^{a}$ Estimates and significance based on contrasts from ANOVA of arcsine (square root) transformation of unadjusted percent germination. Differences in percent germination adjusted for viability of $S$. gesnerioides seeds are presented.

${ }^{\mathrm{b}}$ NS, not significant; $* *, P \leq 0.01$.

c All Vigna cultivars does not include V. subterranea cv. Tvsu745 for this estimate.

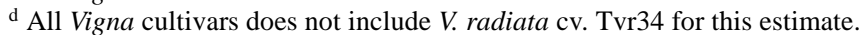


tween cultivar Tvr34 and cultivars 86711 or Tvsu745.

Adjusted germination of $S$. gesnerioides seeds stimulated by C. cajan and Sphenostylis stenocarpa ranged from 0 to $21.8 \%$ and from 3.7 to $11.6 \%$, respectively. None of these accessions stimulated as much germination as did the cultivars Tvsu745, Tvr34, and 86711. Two accessions of $L$. purpureus stimulated significant amounts of germination but less than that of the aforementioned three cultivars.

As a species, Sorghum bicolor did not stimulate significantly more germination than any other species (Table 3). However, one landrace of Sorghum bicolor, Bagauda farafara, stimulated significantly more germination than any other cultivar or accession, including the aforementioned cultivars 86711 and Tvsu745 (Tables 4 and 5). By indirect comparison, this sorghum landrace also stimulated significantly more germination than $V$. radiata cultivar Tvr34, since the latter stimulated less (statistically equal) germination than Tvsu745 (Table 5). Although one other Sorghum bicolor landrace (Kano farafara) stimulated germination (Table 4), most accessions had no effect.

Interactions of $S$. gesnerioides isolates with cowpea and cereal landraces. When tested with 12 isolates of S. gesnerioides, the cowpea cultivar IT84S-2246-4 stimulated significant $(P \leq 0.01)$ germination (data not shown) of only six of the parasite isolates (Akayafi, Balbadu, Bauchi, Bulkachuwa, Darazo, and Sade). Subsequent tests with landraces of sorghum (Table 6) showed that seeds of eight of the isolates were stimulated to germinate by root pieces of a least one sorghum landrace. Seeds of all isolates except Dorum were stimulated to germinate by either the cowpea cultivar or at least one landrace of sorghum.

Tests with millet and sorghum landraces and seeds of the $12 \mathrm{~S}$. gesnerioides isolates showed that seeds of only one S. gesnerioides isolate (Balbadu) germinated in response to root pieces from one millet landrace (Chilarye). For sorghum, 13 of the 540 possible landrace-isolate combinations resulted in percentage germination significantly above zero (Table 6). The sorghum-parasite combinations that resulted in seed germination in the first series of tests, and for which there was adequate material to test once or twice more, resulted in seed germination in subsequent tests (Table 6). In no case did seeds of $S$. gesnerioides germinate in one test and not germinate in other tests. Randomly selected combinations of landraces and isolates that resulted in no germination in the first test also resulted in no germination when tested again. Differential effects of landrace-parasite isolate combinations that resulted in parasite seed germination were observed. Although seeds of all of the isolates presented in Table 6 were stimulated to germinate by at least one sorghum landrace, they did not uniformly respond to stimulation by the different landraces.

\section{DISCUSSION}

Species of Vigna other than the host, $V$. unguiculata, stimulated relatively high percentages of $S$. gesnerioides seeds to germinate in tests with the Bagauda population, although there was variation among cultivars. Increasing the number of laboratory tests and decreasing the concomitant standard error would likely improve our ability to differentiate the more effective cultivars of the species tested. However, one cultivar of $V$. radiata and one of $V$. subterranea stimulated significantly more germination than did the most effective cultivar of $V$. unguiculata. These cultivars of $V$. radiata and $V$. subterranea possibly could be used in crop rotations to reduce the amount of $S$. gesnerioides seeds in soil, but only $V$. subterranea is cultivated to any extent in Africa. The other species would not likely be farmer-acceptable replacements for $V$. unguiculata. Other than $V$. unguiculata, the species of Vigna tested in this study have not been reported to be hosts of $S$. gesnerioides, but they cannot conclusively be excluded as hosts. The morphotype specificity common to $S$. gesnerioides $(15,17,24)$ may merely preclude parasitism of other species by $S$. gesnerioides isolates from $V$. unguiculata. To our knowledge, the ability of other morphotypes of $S$. gesnerioides to parasitize other Vigna species has not been tested.

The effects of the species $C$. cajan and Sorghum bicolor on germination of $S$. gesnerioides seeds have been reported previously (19), but only C. cajan was found to stimulate levels of germination approaching that of $V$. unguiculata. From these studies, it appeared that cultivars of the nonhosts C. cajan, Sphenostylis stenocarpa, L. purpureus, and Sorghum bicolor could be selected and used in a crop rotation program to reduce the amount of $S$. gesnerioides seed in soil. (L. purpureus may be a farmer-acceptable forage crop, and the other three species are cultivated as food crops in Africa.) With the exception of the sorghum cultivar Bagauda farafara, adjusted germination for the most effective cultivars of the other three species was only between 11.6 and $21.8 \%$. However, these results were obtained with only $1.5 \mathrm{~g}$ of root pieces of 3-week-old seedlings. In a field situation, each plant of these cultivars would produce substantially more roots and stimulate parasite seed germination throughout the growing season. In the case of $S$. hermonthica, the relative effectiveness of laboratory selections of soybean and cowpea cultivars has been highly correlated $(r>0.90)$ with effectiveness in reducing parasitism on susceptible sorghum in field studies $(5,6,8)$. Field validation of the effectiveness of selected nonhost cultivars is warranted if they are to be used in a rotation program for $S$. gesnerioides control. Since root density can be expected to influence effectiveness in stimulating parasite germination, planting density also should be considered in field validation studies.

The high amount of germination stimulated in the Bagauda population of $S$. gesnerioides by the sorghum cultivar Bagauda farafara suggested that certain sorghum cultivars might be very effective in rotation with cowpea for $S$. gesnerioides control. This response also suggested that there

Table 6. Germination of seeds of Striga gesnerioides isolates (out of 12 tested) stimulated by landraces of sorghum (out of 45 tested)

\begin{tabular}{|c|c|c|c|c|c|c|c|c|}
\hline \multirow[b]{2}{*}{ Sorghum landrace } & \multicolumn{8}{|c|}{ S. gesnerioides isolate (\% seed germination) ${ }^{a}$} \\
\hline & Bulkachuwa & Darazo & Fandi & Ningi & Sade & Yana & Zandan & Zigau \\
\hline Chilarye & $\ldots$ & $\ldots^{\mathrm{b}}$ & $\ldots$ & 35.6 & $\ldots$ & $\ldots$ & $\ldots$ & $\ldots$ \\
\hline Danbuwa & 43.4 & $\ldots$ & $\ldots$ & $36.5^{\mathrm{c}}$ & $\ldots$ & $\ldots$ & $\ldots$ & $\ldots$ \\
\hline Kanda & $\ldots$ & $\ldots$ & $\ldots$ & $\ldots$ & $\ldots$ & $\ldots$ & $\ldots$ & 19.9 \\
\hline Ketawa & $\ldots$ & 20.9 & $\ldots$ & 88.9 & $\ldots$ & $\ldots$ & $\ldots$ & 55.6 \\
\hline Ningi & $\ldots$ & $\ldots$ & $\ldots$ & $\ldots$ & $0^{\mathrm{d}}$ & 28.8 & $\ldots$ & $\ldots$ \\
\hline Wasai & $\ldots$ & $\ldots$ & 43.0 & $\ldots$ & $\ldots$ & 0 & $\ldots$ & $\ldots$ \\
\hline Yana & $\ldots$ & 0 & $\ldots$ & $\ldots$ & 43.7 & $\ldots$ & $\ldots$ & $\ldots$ \\
\hline Zandan & 27.2 & $\ldots$ & 0 & $31.7^{\mathrm{c}}$ & $\ldots$ & $\ldots$ & $31.5^{\mathrm{c}}$ & $\ldots$ \\
\hline
\end{tabular}

${ }^{a}$ Germination adjusted, after statistical analysis, for seed viability of the different $S$. gesnerioides isolates. Unless otherwise specified, the figures represent significant $(P \leq 0.01)$ germination based on three tests. Significance was determined by analysis of arcsine (square root) transformation of unadjusted percent germination of each combination in each test.

${ }^{\mathrm{b}}$ No significant germination in first test; not tested in second and third tests.

c Significant $(P \leq 0.01)$ germination based on two tests.

${ }^{\mathrm{d}}$ No significant germination based on three tests. 
might be some specificity in parasite seed germination, i.e., the greatest amount of germination between combinations of cereal cultivars and $S$. gesnerioides isolates from the same location. Tests with sorghum and millet landraces and isolates of $S$. gesnerioides showed that millet was ineffective in stimulation of $S$. gesnerioides seed germination, as only one of 540 millet landrace-isolate interactions resulted in germination. However, sorghum landraces showed a high degree of specificity in ability to stimulate germination of seeds of $S$. gesnerioides isolates. With the exception of the Zandan-Zandan combination of landrace and isolate, this specificity was not, however, between the same locations of landraces and isolates (Table 6). Unfortunately, this specificity probably precludes the likelihood of selecting sorghum germ plasm that would be universally effective in a rotation program for $S$. gesnerioides control. However, the potential appears to exist for selecting sorghum germ plasm on a very local-specific basis for control of the isolate(s) within the locality. Given the simplicity and low cost of the laboratory procedure, selection of effective cultivars within localities may be practicable.

The cowpea cultivar IT84S-2246-4, which is generally regarded as susceptible to $S$. gesnerioides, stimulated significant germination of parasite seeds of the $\mathrm{Ba}-$ gauda population. However, this cultivar stimulated seeds of only six of the $12 \mathrm{~S}$. gesnerioides isolates tested to germinate, although the parasite seeds were viable. Five of the isolates (Fandi, Ningi, Yana, Zandan, and Zigau) that were not stimulated to germinate by the cowpea cultivar were stimulated to germinate by at least one sorghum landrace. The isolates Bulkachuwa, Darazo, and Sade were stimulated to germinate by both the cowpea cultivar and at least one sorghum landrace. However, only a few sorghum landraces stimulated germination of $S$. gesnerioides isolates, and these interactions were very specific.

There are several implications of these latter results that deserve further investigation. A cowpea cultivar, generally regarded as susceptible to $S$. gesnerioides, may be capable of stimulating germination of only a fraction of viable seeds from populations of $S$. gesnerioides to which it is exposed. The same may be true of selected nonhost cultivars, e.g., Bagauda farafara. If these phenomena exist, they may be due to a plethora of both specific stimulant receptors among isolates of $S$. gesnerioides and germination stimulants among host and nonhost plants. The existence of many morphotypes, strains, and races of $S$. gesnerioides with overlapping distributions $(13-18,20)$ suggests that this may be true.

A variety of different receptors (particularly within any given population of $S$. gesnerioides) might enhance survival of the parasites. Certain "rare" receptors in an $S$. gesnerioides population might ensure that after exposure to more common stimulants (perhaps from a nonhost), a small reservoir of ungerminated but viable seeds remain in the soil. These seeds might remain dormant until they are exposed to an appropriate germination stimulant (ideally from a host plant) or until they are no longer viable. Conversely, populations of $S$. gesnerioides that possess relatively few stimulant receptors might be endangered by relatively few nonhosts (including weedy species) that produce the right stimulants to germinate all parasite seeds. Without encountering a host that produces the right stimulant for relatively few receptors, these populations might also be exposed to extermination through loss of seed viability.

Furthermore, plants (particularly hosts) that fail to stimulate germination of seeds of an S. gesnerioides isolate might not be conclusively ruled out as stimulant producers. They might actually produce a germination stimulant that is simply not recognized by the receptors of seeds of the particular isolate.

\section{ACKNOWLEDGMENTS}

We thank K. S. Nokoe of the biometrics unit of IITA for his advice and review of the statistical analysis. We also thank I. A. Hammed, F. O. Ikie, and A. Moors for their technical assistance. Approved as International Institute of Tropical Agriculture manuscript number IITA/96/JA/55.

\section{LITERATURE CITED}

1. Aggarwal, V. D. 1985. Cowpea Striga research. Pages 335-340 in: Cowpea Research, Production, and Utilization. S. R. Singh and K. O. Rachie, eds. John Wiley \& Sons, London.

2. Aggarwal, V. D., and Ouedraogo, J. T. 1989. Estimation of cowpea yield loss from Striga infestation. Trop. Agric. 66:91-92.

3. Anonymous. 1990. Grain legume improvement. Pages 51-58 in: International Institute of Tropical Agriculture Annual Report 1989/90. International Institute of Tropical Agriculture, Ibadan, Nigeria.

4. Bebawi, F. E., Eplee, R. E., Harris, C. E., and Norris, R. S. 1984. Longevity of witchweed (Striga asiatica) seed. Weed Sci. 32:494-497.

5. Berner, D., Carsky, R., Dashiell, K., Kling, J., and Manyong, V. A. 1996. Land management based approach to integrated Striga hermonthica control in sub-Saharan Africa. Outlook Agric. 25:157-164.

6. Berner, D. K., Kling, J. G., and Singh, B. B. 1995. Striga research and control: A perspective from Africa. Plant Dis. 79:652-660.

7. Bressani, R. 1985. Nutritive value of cowpea. Pages 353-360 in: Cowpea Research, Production, and Utilization. S. R. Singh and K. O. Rachie, eds. John Wiley \& Sons, Chichester, UK.

8. Carsky, R. J., and Berner, D. K. 1995. Benefits of crop rotation with soybean and cowpea in savanna cereal based systems. Pages 391402 in: SAFGRAD regional workshop on technology options and transfer systems for food and grain production in sub-Saharan Africa. 26-28 April 1995, Abidjan, Cote d'Ivoire.

9. Emechebe, A. M., Singh, B. B., Leleji, O. I., Atokple, I. D. K., and Adu, J. K. 1991. Cowpea-Striga problems and research in Nigeria. Pages 18-28 in: Combating Striga in Africa. S. K. Kim, ed. Proc. Int. Workshop IITA, ICRISAT, and IDRC. 22-24 August 1988. ITTA,
Ibadan, Nigeria.

10. Hussain, H. S. N., and Aigbokhan, E. I. 1991 Growth stages of Striga gesnerioides on cowpea roots. Pages 279-286 in: Proc. Int. Symp. Parasitic Weeds, 5th. J. K. Ransom, L. J. Musselman, A. D. Worsham, and C. Parker, eds. CIMMYT, Nairobi.

11. Igbinnosa, I., and Okonkwo, S. N. C. 1991. Screening of tropical legumes for the production of active germination stimulants and for resistance to Nigerian cowpea witchweed (Striga gesnerioides). Nigerian J. Weed Sci. 4:1-9.

12. Kuijt, J. 1977. Haustoria of phanerogamic parasites. Annu. Rev. Phytopathol. 17:91-118.

13. Lane, J. A., Moore, T. H. M., Child, D. V., and Cardwell, K. F. 1996. Characterization of virulence and geographic distribution of Striga gesnerioides on cowpea in West Africa. Plant Dis. 80:299-301.

14. Lane, J. A., Moore, T. H. M., Child, D. V. Cardwell, K. F., Singh, B. B., and Bailey, J. A. 1994. Virulence characteristics of a new race of the parasitic angiosperm Striga gesnerioides from southern Benin on cowpea. Euphytica 72:183-188.

15. Musselman, L. J. 1980. The biology of Striga, Orobanche, and other root-parasitic weeds. Annu. Rev. Phytopathol. 18:463-489.

16. Musselman, L. J., Bhrathalakshmi, S., Safa, B., Knepper, D. A., Mohamed, K. I., and White, C. L. 1991. Recent research on the biology of Striga asiatica, S. gesnerioides, and S. hermonthica. Pages 31-41 in: Combating Striga in Africa. S. K. Kim, ed. Proc. Int. Workshop IITA, ICRISAT, and IDRC. 22-24 August 1988. IITA, Ibadan, Nigeria.

17. Musselman, L. J., and Parker, C. 1981. Studies on indigo witchweed, the American strain of Striga gesnerioides (Scrophulariaceae). Weed Sci. 29:594-596.

18. Parker, C., and Polniaszek, T. I. 1990. Parasitism of cowpea by Striga gesnerioides: Variation in virulence and discovery of a new source of host resistance. Ann. Appl. Biol. 116:305-311

19. Parker, C., and Reid, D. C. 1979. Host specificity in Striga species-some preliminary observations. Pages 79-90 in: Proc. Symp. Parasitic Weeds, 2nd. L. J. Musselman, A. D. Worsham, and R. E. Eplee, eds. North Carolina State University, Raleigh.

20. Parker, C., and Riches, C. R. 1993. Striga and Alectra on cowpea and other broadleaved crops. Pages 75-109 in: Parasitic Weeds of the World. C. Parker and C. R. Riches, eds. CAB International, Walllingford, UK.

21. Sand, P. F., and Manley, J. D. 1990. The witchweed eradication program survey, regulatory and control. Pages 141-151 in: Witchweed Research and Control in the United States. P. F. Sand, R. E. Eplee, and R. G. Westerbrooks, eds. Weed Sci. Soc. Am. Champaign, IL.

22. Singh, B. B., and Emechebe, A. M. 1990 Inheritance of Striga resistance in cowpea genotype B301. Crop Sci. 30:879-881.

23. Steele, W. M. 1976. Cowpeas. Pages 183-185 in: Evolution of crop plants. N. W. Simmonds, ed. Longman Group UK LTD, Harlow Essex, Eng.

24. Vasudeva Rao, M. J., and Musselman, L. J. 1987. Host specificity in Striga spp. and physiological "strains". Pages 13-25 in: Parasitic Weeds in Agriculture. Vol. 1, Striga. L. J. Musselman, ed. CRC Press, Boca Raton, FL.

25. Wild, H. 1948. A suggestion for the control of tobacco witchweed (S. gesnerioides (Willd.) Vatke) by leguminous trap crops. Rhodesia Agric. J. 48:208-215.

26. Worsham, A. D. 1987. Germination of witchweed seeds. Pages 45-61 in: Parasitic Weeds in Agriculture. Vol. 1, Striga. L. J. Musselman, ed. CRC Press, Boca Raton, FL. 